\title{
Chemokine-binding proteins encoded by herpesviruses
}

\author{
M. BENKO, S. LENHARTOVÁ, V. KEMPOVÁ, T. BETÁKOVÁ, M. KÚDELOVÁ*
}

Institute of Virology, Biomedical Research Center Slovak Academy of Sciences, Dúbravská cesta 9, 84505 Bratislava, Slovak Republic

\begin{abstract}
Summary. - To establish infection, a wide variety of pathogens, including viruses, have evolved a number of strategies to avoid immune elimination. Viruses have acquired and optimized molecules that interact with the host chemokine network in order to disrupt immune surveillance and defense of vertebrates, helping to promote cell entry, facilitating dissemination of infected cells, and evasion the immune response. Viral immunomodulators include ligands, chemokine receptors and chemokinebinding proteins (vCKBPs) functioning as either cell surface receptor mimics, ligand mimics, or secreted chemokine-binding proteins. vCKBPs specifically modulate chemokine gradient formation and ligandreceptor recognition when they have a potential to even completely block chemokine-mediated responses to viral infection. Members of only two virus families (Herpesviridae and Poxviridae) encode vCKBPs capable of sequestering host chemokines through either the chemokine receptor, GAG-binding pocket, or both, which may result in the inhibition of chemotaxis in vivo. Here, we focused on vCKBPs encoded by $\alpha-, \beta-$, and $\gamma$-herpesviruses, of which several have been experimentally used as anti-inflammatory or anti-immune reagents in animal models. Current results suggest that vCKBPs could be used to regulate the activity of both chemokines and chemokine receptors for the treatment of infections such as AIDS, diseases such as arthritis, neurotrauma, inflammatory CNS disorders, atherosclerosis, transplant rejection, and metastatic spread and angiogenesis. Better understanding of vCKBPs biology will help evaluate, which human diseases related to chemokine network dysregulation might be effectively treated with these novel promising immunomodulatory drugs to enable the manipulation of chemokine functions and leukocyte trafficking.
\end{abstract}

Keywords: herpesviruses; chemokine-binding proteins; chemokines; immunomodulation viral infection, chemokines and viral immunomodulators

\section{Introduction}

To establish infection, a wide variety of pathogens, including viruses, have evolved a number of strategies

"Corresponding author. E-mail: virukude@savba.sk; phone: +421-2-59302-434.

Abbreviations: $\mathrm{CNS}=$ central nervous system; EBV = EpsteinBarr virus; EHV-1 = equine herpesvirus-1; FeHV-1 = felid herpesvirus-1; GAGs = glycosaminoglycans; $g G$ = glycoprotein G; GPCR = G-protein coupled receptor; HCMV = human cytomegalovirus; HHV = human herpesvirus; HSV-1/2 = herpes simplex virus $1 / 2$; ILTV = infectious laryngotracheitis virus; KSHV = Kaposi's sarcoma herpesvirus; MHV-68/72 = murine herpesvirus 68/72; PRV = pseudorabies virus; $R H V P=$ rodent herpesvirus Peru; SgG = secreted gG; vCKBP-viral chemokine binding protein; $\mathrm{VZV}$ = varicella zoster virus to avoid immune elimination. They target chemokinesignaling networks in order to disrupt immune surveillance and defense of vertebrates. Small soluble peptides of the cytokine family, known as chemokines, are ligands that trigger many signaling cascades involved in innate immunity via binding to their receptors on the surface of immunocompetent cells. Many viruses have developed strategies to overcome this signal transduction, which implies its significant role in the battle against both acute and persistent viral infection, the outcome of which depends on the balance between host immune responses and viral immune evasion. These strategies involve hiding in certain cell types to escape from the attention of the immune system, inhibiting the replication of infected cells to limit antigen production, subverting cytokine-mediated intercellular communication by viral immunomodula- 
tors, and increasing the generation of viral mutants $(\mathrm{Hu}$ and Usherwood, 2014).

Chemokines are low molecular weight (8-12 kDa) chemoattractant cytokines that modulate the migration of immune cells from blood vessels to the sites of infection and inflammation and therefore play an important role in host defense against invading pathogens (Luster, 1998, Baggiolini, 1998). They establish gradients through specific interactions with glycosaminoglycans (GAGs) and direct target cell migration and activation by binding to $G$ protein-coupled chemokine receptors (Allen et al., 2007). It has been established that chemokines are associated with disease progression and are also implicated to operate during development, homeostasis, angiogenesis, tissue damage, and in acute lung allograft rejection (Rollins, 1997; Belperio et al., 2000a,b; Charo and Taubman, 2004; Chow and Luster, 2014; Luo et al., 2016).

Chemokines show remarkably similar structure, although their mutual sequence homology varies between 20-90\%. These proteins are defined by four invariant cysteines and are structurally classified into four structural subfamilies as CC, $\mathrm{CXC}, \mathrm{CX}_{3} \mathrm{C}$, and $\mathrm{C}$ based on the number and $\mathrm{N}$-terminal sequence arrangement around the first two conserved cysteines. Despite the differences in the primary structure, chemokines share similar structures of a long flexible $\mathrm{N}$ terminal loop followed by a threestranded $\beta$ sheet and a C-terminal $\alpha$ helix (Fernandez and Lolis, 2002). As basic and positively charged molecules, chemokines form a chemical gradient via electrostatic interactions of their C-terminus, interacting with negatively charged extracellular GAGs expressed on the endothelial cell surface that can act to directionally attract cells into the target tissues (Ali et al., 2000; Proudfoot et al., 2003; Burg et al.,2015). This chemokine-GAG complex is then via the N-terminus of chemokines recognized by conserved motifs of seven transmembrane spanning $G$ proteincoupled receptors (GPCRs) that are localized on the surface of the attracted leukocytes (Mantovani et al., 2006; Monneau et al., 2015). The specific effects of chemokines are mediated by the subsequent intracellular cascade of signaling events leading to, among others, migration of immunocompetent cells to the site of inflammation in the respective tissues (Sallusto and Baggiolini, 2008). Chemokines can interact with both GAGs and chemokine receptors simultaneously through distinct domains, although these domains may overlap for some chemokines. Given the central role chemokines play in antiviral defense, it is not surprising that many viruses have evolved strategies to modulate host chemokine function to their benefit (Alcami and Koszinowski, 2000).

Chemokines form the largest family of cytokines, with approximately 50 chemokines and 20 chemokine receptors discovered to date. Most receptors interact with more than one chemokine and most chemokines use more than one receptor. The original names of individual chemokines such as monocyte chemotactic protein-1 (MCP1), macrophage inflammatory protein-1a (MIP-1a), stromal cell-derived factor-1 (SDF1), eotaxin, or regulated-on-activation normal $\mathrm{T}$ cell expressed and secreted (RANTES) reflected the circumstances of their discovery, but not always their most important role. To make it more complicated, some chemokines had several names, which reflected the diversity of their actions. In 1999, when more than 40 different human chemokines had been discovered, a systematic chemokine nomenclature was adopted based on their structural features (Fernandez and Lolis, 2002; Zlotnik and Yoshie, 2012).

Chemokine receptors are 7 transmembrane GPCRs that signal through heterotrimeric $G$ proteins. There are, however, also atypical chemokine receptors that act as chemokine scavengers and do not induce $\mathrm{G}$ protein signaling (Bachelerie et al., 2014a,b). The binding sites of chemokines for GAGs and specific cytokine receptors (CKRs) are distinct. Chemokine receptors can be classified in the same manner as chemokines (C, CC, CXC, and CX3C) and are either inducible (inflammatory) or constitutively expressed (Murdoch and Finn, 2000; Proudfoot, 2002). Although most chemokine receptors recognize more than one chemokine, they are almost always restricted to a single subclass.

The chemokines and some of their receptors are both redundant and promiscuous, often crossing class activities and receptor affiliations (Zlotnik and Yoshie, 2012). Both chemokines and chemokine receptors have been implicated in the initiation and progression of infections such as AIDS or many diseases, including arthritis, glomerulonephritis, neurotrauma, inflammatory CNS disorders, atherosclerosis, myocardial damage, lung diseases, transplant rejection, among many others (Campbell et al., 2003; Johnson et al., 2004; Ludwig and Weber, 2007; Weber et al., 2013). The regulation of the activity of both chemokines and chemokine receptors to prevent excessive inflammation causing disease represents important target for therapeutic intervention.

Viruses have acquired and optimized molecules that interact with the host chemokine network. These virusencoded molecules are used to promote cell entry, facilitate dissemination of infected cells, and evade the immune response. Viral immunomodulators of chemokines interfere with extracellular chemokines. They target or bind to chemokines and their receptors and thus specifically modulate chemokine gradient formation and ligand-receptor recognition; they have a potential to even completely block chemokine-mediated responses in viral infection. Virusencoded immunomodulatory proteins have been identified from many virus families, with the majority being 
Table 1. Virus encoded binding proteins (vCKBPs) and their targets

\begin{tabular}{|c|c|c|c|c|c|c|c|}
\hline $\begin{array}{l}\text { vCKBP } \\
\text { type }\end{array}$ & $\begin{array}{l}\text { Virus } \\
\text { family }\end{array}$ & \multicolumn{2}{|l|}{ Virus } & vCKBP & $\begin{array}{l}\text { Target - class } \\
\text { chemokines }\end{array}$ & $\begin{array}{l}\text { Binding } \\
\text { domain/s }\end{array}$ & References \\
\hline I & Poxviridae & \multicolumn{2}{|l|}{ myxoma poxvirus } & $\begin{array}{l}\text { M-T7/35F kDa } \\
\text { protein }\end{array}$ & C, CC, CXC & GAG & $\begin{array}{l}\text { Upton et al. (1992) } \\
\text { Lalani et al.(1997) } \\
\text { Mossman et al.(1996) }\end{array}$ \\
\hline II & Poxviridae & \multicolumn{2}{|c|}{$\begin{array}{l}\text { myxoma poxvirus } \\
\text { certain vaccinia strains } \\
\text { rabbit pox virus } \\
\text { cowpox viruses }\end{array}$} & $\begin{array}{l}\text { different } \\
\text { proteins called } \\
\text { CC-inhibitors } \\
\text { (vCCIs) }\end{array}$ & CC & GAG & $\begin{array}{l}\text { Alcami et al. (1998) } \\
\text { Smith et al. (1997) } \\
\text { Lalani et al. (1998) } \\
\text { Reading et al. (2003) }\end{array}$ \\
\hline \multirow[t]{3}{*}{ IV } & \multirow[t]{3}{*}{ Herpesviridae } & \multirow{3}{*}{ a-herpesviruses } & HSV-1 & gG & $\mathrm{CC}, \mathrm{CXC}$ & GPCR & Bryant et al.(2003) \\
\hline & & & $\begin{array}{l}\text { HSV-2 } \\
\text { EHV-1 } \\
\text { BoHV-1 } \\
\text { BoHV-5 }\end{array}$ & & \multirow[t]{2}{*}{$\begin{array}{l}\text { C, CC, CXC } \\
\text { (different set of } \\
\text { chemokines depend- } \\
\text { ing on the virus) }\end{array}$} & \multirow[t]{2}{*}{$\begin{array}{l}\text { GPCR } \\
\text { GAG }\end{array}$} & $\begin{array}{l}\text { Viejo-Borbolla et al. (2012) } \\
\text { von Einem et al. (2007) } \\
\text { Engelhardt and Keil, } \\
(1996)\end{array}$ \\
\hline & & & $\begin{array}{l}\text { FeHV-1 } \\
\text { PRV } \\
\text { ILTV }\end{array}$ & & & & $\begin{array}{l}\text { Costes et al. (2005) } \\
\text { Viejo-Borbolla et al. (2010) } \\
\text { Devlin et al. (2010) }\end{array}$ \\
\hline $\mathbf{V}$ & & $\beta$-herpesvirus & HCMV & pUL21.5 & $\begin{array}{l}\text { CCL5 } \\
\text { (a single tested) }\end{array}$ & GPCR & Wang et al. (2004) \\
\hline \multirow[t]{2}{*}{ III } & & $\gamma$-herpesviruses & MHV-68 & M3 & $\begin{array}{l}\text { C, CC, CXC, CX3C } \\
\text { (a single found to in- } \\
\text { hibit all four classes } \\
\text { of chemokines) }\end{array}$ & $\begin{array}{l}\text { GPCR } \\
\text { GAG }\end{array}$ & $\begin{array}{l}\text { Alexander et al. (2002) } \\
\text { Alcami (2003b) } \\
\text { van Berkel et al. (2000, } \\
2002) \\
\text { Parry et al. (2000) } \\
\text { Webb et al. }(2003)\end{array}$ \\
\hline & & & RHVP & $\mathrm{R} 17$ & $\mathrm{C}, \mathrm{CC}$ & $\begin{array}{l}\text { GPCR } \\
\text { GAG }\end{array}$ & Lubman et al. (2014) \\
\hline
\end{tabular}

derived from DNA viruses (McFadden and Murphy, 2000; Seet et al., 2003, Lalani et al., 2000; Alcami and Lira, 2010).

To date, three classes of molecules that interact with the chemokine system have been identified: viral chemokine ligands, viral chemokine receptors, and chemokine-binding proteins functioning as either cell surface receptor mimics, ligand mimics, or secreted chemokine-binding proteins. Viral chemokines have been shown to function as agonists and/or antagonists in their interactions with mammalian chemokine receptors. Acting as agonists, they facilitate viral infection and dissemination; as antagonists they inhibit the recruitment of specific leukocyte populations, thus contributing to immune evasion.

The role of viral chemokine receptors in viral pathogenesis is not fully understood. Recent studies have implicated virally encoded chemokine receptors in the proliferation and migration of cells as well as in the pathogenesis of Kaposi's sarcoma caused by human herpesvirus 8 or Kaposi's sarcoma herpesvirus (HHV-8 or KSHV, respectively). Viral chemokine receptors and viral chemokines share high degrees of identity with host proteins and thus are categorized as pirated host immune regulators, whose biologic functions have been altered by subsequent evolutionary pressures within virus-infected hosts (Vossen et al., 2002; Zlotnik et al., 2006). The properties of such shaped host-derived immunomodulators represent specific advantages for the virus in overcoming the immune defenses of the host (Alcami, 2003a). The most recently discovered class of virus-encoded molecules capable of interfering with chemokine function are viral chemokine-binding proteins (vCKBPs).

The first secreted chemokine decoy receptor, discovered in orthopoxviruses and called $35 \mathrm{kDa}$, is a protein with the ability to interact with CC chemokines (Graham et al., 1997; Smith et al., 1997). To date, a wide spectrum of vCKBPs has been discovered that are encoded by poxviruses from the Orthopoxvirus or Leporipoxvirus genera such as camelpox, cowpox (CPXV), rabbitpox, raccoonpox, vaccinia virus (VACV), Lister strain, variola virus (VARV), leporipoxviruses myxoma virus (MYXV), and Shope fibroma virus. Their binding to chemokines was initially identified by cross-linking experiments with chemokines and supernatants from cells infected with viruses. Their interaction with only CC chemokines resulting in the inhibition of chemokine activity was documented in vitro and in vivo using site-directed mutagenesis methods (Alcami et al.,1998; Lalani et al.,1998; Burns et al., 2002; Kuo et al., 2014).

No significant homology to mammalian protein was shown in known vCKBPs. They also have very little or 
no sequence relationship with any known host proteins, including host chemokines or receptors, suggesting that they may have evolved independently of mammalian genomic elements. Moreover, they display a very limited homology with vCKBPs identified in different viruses (Heidarieh, 2015). Despite this fact, the crystal structures of several vCKBPs show common structural patterns, suggesting that they probably underwent simultaneous evolutionary processes (Nelson et al., 2015; Lubman and Fremont, 2016). The origin of this group of immunomodulators, probably also derived from unknown ancient host species, remains unresolved. vCKBPs were found to bind and inhibit specific host ligands in experiments using host chemokines (Seet and McFadden, 2000, Parry et al., 2000; Alexander et al., 2002). Some, for example, M-T7 protein encoded by MYXV, interact with C, CC, and CXC chemokines with very low-affinity proteoglycan-binding sites conserved in many chemokines. Other members of the chemokine-binding protein class disrupt the interaction of chemokine ligands with their cellular receptors.

Based on the available structural and functional studies, vCKBPs are currently divided into five structural classes through the mechanisms of their binding to chemokines, but most remain undefined (Table 1). To date, all known vCKBPs have been discovered in large DNA viruses from the Poxviridae and Herpesviridae families. They encode unique proteins capable of sequestering host chemokines with distinct specificity. vCKBPs bind to the chemokine through either its chemokine receptor or GAG-binding pocket or both, thereby impairing the interaction between the chemokine and its receptor or GAGs. Both types of binding impairment may result in the inhibition of chemotaxis in vivo. Similar to chemokines, most vCKBPs are secreted proteins but some are also structural proteins present in the viral envelope or at the plasma membrane of infected cells (Bryant et al., 2003; Costes et al., 2005; Viejo-Borbolla et al., 2012). Similar to chemokines, some vCKBPs interact with GAGs, which seems to be relevant for their function (Seet et al., 2001; Ruiz-Arguello et al., 2008; Lubman et al., 2014; MartinezMartin et al., 2015). While the majority of known vCKBPs inhibit chemokine activity in vitro or in vivo, a vCKBP with the ability to potentiate chemokine function was recently found in herpes simplex virus type 1 and 2 (HSV-1 and -2) (or human herpesvirus 1; HHV-1 and -2), respectively (Viejo-Borbolla et al., 2012).

\section{Chemokine-binding proteins encoded by herpesviruses}

It has been established that molecular mimicry of cytokines and cytokine receptors is a strategy adopted by herpesviruses to modulate the host immune response (Spriggs, 1996, Dairaghi et al., 1998, Alcami and Lira, 2010, Heidarieh et al., 2015, Lubman and Fremont, 2016). Herpesviruses are enveloped viruses that contain large doublestranded DNA with vast coding capacity. Approximately 130 different herpesviruses have been identified, not only in mammals, but also in frogs, lizards, birds, fish, and mosquitoes. They constitute an ancient virus family that has fully adapted to their hosts as demonstrated by high infection rates in most human populations. The natural infection of herpesviruses has three stages: primary infection, latency, and reactivation. During lytic replication, numerous viral genes are expressed in a highly ordered manner, leading to the assembly and release of infectious particles, often resulting in the lysis of infected cells (Roizman and Pellet, 2001).

Unique vCKBPs have been identified in all three subfamilies of herpesviruses. To date, chemokine-binding activity has been identified in the supernatants from diverse cell lines infected with HSV-1 and HSV-2 and several animal herpesviruses such as equine herpesvirus 1 and 3 (EHV-1 and EHV-3, respectively), bovine herpesvirus 1 and 5 (BoHV-1 and BoHV-5, respectively), feline herpesvirus 1 (FeHV-1), infectious laryngotracheitis virus (ILTV), pseudorabies virus (PRV), murine herpesvirus 68 (MHV-68), and rodent herpesvirus Peru (RHVP). Such proteins have not yet been discovered in other human herpesviruses - varicella zoster virus or human herpesvirus 3 (VZV or HHV-3), human herpesvirus 6A and B (HHV-6A and B), human herpesvirus 7 (HHV-7), Epstein-Barr virus or human herpesvirus 4 (EBV or HHV-4), KSHV, and animal herpesvirus, Marek disease virus 1 (MDV-1).

\section{Chemokine-binding proteins encoded by a-herpesviruses}

Members of the Alphaherpesvirinae subfamily are characterized by a broad host range. They are highly lytic in culture and as neurotropic viruses have the ability to establish latent infections primarily in host ganglia of the peripheral nervous system. They cause a variety of diseases: neurological disorders, encephalitis, meningitis, blindness, chickenpox, shingles, skin lesions, and abortion, among others.

In $\alpha$-herpesviruses, to date the only one vCKBP (designated as type IV) has been identified, glycoprotein $G$ (gG), encoded by the US4 open reading frame (ORF) (Bryant et al., 2003). The gene encoding gG is present in most human and animal $\alpha$-herpesviruses with the notable exceptions of VZV and MDV-1 (Ross et al., 1991, McGeoch et al.,1990).gG from $\alpha$-herpesviruses is a component of the viral particle that is expressed as a membrane-anchored 
glycoprotein at the plasma membrane of infected cells. After proteolytic cleavage of this membrane form, an additional secreted gG (SgG) is released into the medium of infected cells. The role of HSV-1 gG has been addressed in the mouse model. Intracerebral infection of mice with HSV-1 deleted in gG gene results in lower levels of virus replication in the central nervous system (CNS) (Weber et al., 1997). The role of HSV-2 gG in vivo has not been investigated. A report using CCL3 knockout mice showed the relevance of gG inhibition in CCL3-mediated neutrophil migration and subsequent inflammation in the lungs (Van de Walle et al., 2009, Cabrera et al., 2015). Infection with recombinant HSV-1 viruses lacking gG expression in vivo resulted in the attenuation of pathogenesis as suggested by the enhancement of the chemokine function of HSV-1 gG (Balan et al., 1994; Weber et al., 1987). The role of HSV-2 gG in pathogenesis remains unclear since no gG deletion mutants have been reported to date.

The amino acid residues involved in gG interactions with chemokines were first identified by mutagenesis of EHV-1 gG and expression of hybrid molecules with EHV$4 \mathrm{gG}$, an ortholog that does not bind chemokines (Van de Walle et al., 2009). In experiments on mice infected with gG-negative EHV-1, the deletion of gG results in increased EHV-1 pathogenicity, suggesting the presence of a higher inflammatory infiltrate in the lungs of mice (Vande Walle et al., 2008; von Einem et al., 2007). Studies with ILTV, a virus that causes respiratory tract disorders in poultry, indicate that gG modulates leukocyte migration to the infection site. Deletion of gG results in higher levels of inflammatory infiltrate in the trachea of birds (Devlin et al., 2010). Deletion of PRV gG, on the contrary, does not seem to affect virulence or immunogenicity in pigs (Thomsen et al., 1987; Kimman et al., 1992).

Most experiments regarding the chemokine-binding activity of gG of $\alpha$-herpesviruses have been conducted with the secreted form. However, transmembrane gG also binds chemokines at the surface of cells (Viejo-Borbolla et al., 2012) and, at least for FeHV-1, on the viral envelope. The functional relevance of chemokine interactions in these settings is unknown. It has been proposed that transmembrane gG may act as a chemokine sink or may signal following chemokine interactions (Costes et al., 2005). An interesting property of $\alpha$-herpesvirus gG compared to other vCKBPs is that it is a type I transmembrane protein that sheds a secreted domain following proteolytic cleavage. This does not apply to HSV-1 gG, which is not secreted (Richman et al., 1986).

Although chemokine-binding activity has been originally detected in supernatants from HSV-2-infected cultures, it has not been detected in supernatants from cells infected with HSV-1 or VZV. With HSV-1, this is explained by gG not being secreted. The chemokine-binding activ- ity has been detected on the plasma membrane of cells infected with wild-type HSV-1 but not with a gG-deficient HSV-1 mutant, indicating that the membrane-anchored form also retains chemokine-binding activity (ViejoBorbolla et al., 2012). In the case of VZV, the gene encoding gG is not present in the viral genome (Gomi et al., 2002).

The interaction of recombinant SgGs from HSV-1 and HSV-2 with a variety of CC and CXC chemokines occurs with a high affinity through the GAG-binding domain in the chemokines. The mechanism of action of SgGs from HSV is unique among vCKBPs. Similar to almost all CKBPs, gG homologs encoded by other animal a-herpesviruses bind a variety of chemokines (interfering with chemokine interactions with cellular receptors or impairing chemokine presentation to GAGs) resulting in the inhibition of cellular chemotaxis (Martinez-Martin et al., 2015). On the contrary, the interaction of gGs from HSV-1 and HSV-2 with chemokines has the opposite effect, the enhancement of chemokine function. The addition of SgG has recently been shown to increase in vitro CXCL12-induced cell migration and more importantly SgG from HSV-2 has been shown to increase CCL28-mediated chemotaxis of leukocytes in a mouse air pouch model in vivo (Viejo-Borbolla et al., 2012).

Chemokine-binding activity detected in the supernatant of cells infected by animal herpesviruses EHV-1 (von Einem et al., 2007), BoHV-1, BoHV-5 (Engelhardt and Keil, 1996; Bryant et al., 2003), FeHV-1 (Costes et al., 2005), ILTV (Devlin et al., 2010), and PRV (Viejo-Borbolla et al., 2010) was shown to correspond to gG interactions with CC, CXC, and C chemokines and is of a high affinity. However, there is selectivity in the interaction with chemokines, since not all gG proteins interact with the same chemokines or members of the same chemokine subfamily. gG expressed by EHV-1, ILTV, and PRV was confirmed to inhibit chemokine activity in vitro and in vivo (Viejo-Borbolla et al., 2012; Van de Walle et al., 2008; Devlin et al., 2006) by blocking the interaction of the chemokine with its receptor. EHV-1gG has been shown to bind a broad range of chemokines and inhibit equine CXCL8-induced migration of neutrophils. It also prevents the interaction of chemokines with GAGs. The hypervariable region of EHV-1 gG is required for chemokine interaction and the $\mathrm{N}$-glycosylation of gG is essential for its inhibitory activity (Van de Walle et al., 2009). Interestingly, FeHV-1 gG present at the surface of virions has also been demonstrated to bind chemokines (Costes et al., 2006), raising the possibility that incoming virions could interfere with chemokine function. In the case of HSV, it would be interesting to know whether gG incorporated into the virion envelope enhances chemokine function as reported for recombinant SgG. In the case of ILTV, gG was shown to bind murine CC and CXC chemokines with high affinity 
and to inhibit leukocyte chemotaxis. The corresponding gG deletion mutant exhibits an attenuated phenotype in its natural host compared to wild-type virus and is an effective attenuated vaccine since it induces protection against disease following challenge with virulent virus (Devlin et al., 2007).

\section{Chemokine-binding protein encoded by $\beta$-herpesviruses}

Members of the Betaherpesvirinae subfamily contain the largest double-stranded DNA genome among human viruses, have a restricted host range, grow more slowly in culture, and cells infected with this subfamily become enlarged. HCMV is the prototypical member of $\beta$-herpesviruses. Seroepidemiologic studies have shown that HCMV is widespread in the human population. HCMV causes life-threatening diseases in immunologically immature or compromised patients, such as AIDS patients, allogeneic transplant recipients, and developing fetuses. Most healthy adults with HCMV infection are asymptomatic, but the virus evades eradication by the immune system and persists in infected people for the rest of their lives. HCMV is a nearly ubiquitous pathogen that establishes latency in cells of the myeloid lineage. The ability of HCMV to establish life-long latency and avoid extermination by the immune system depends on extensive immune modulation strategies including the ability to antagonize chemokine function.

HCMV expresses a single known vCKBP designated as type V, a small secreted glycoprotein pUL21.5 (103 aa), which functions as a decoy to modulate the host immune response to infection. pUL21.5 has a relatively conserved sequence among clinical isolates, and the presence of UL21.5 mRNA appears to correlate directly with the occurrence of HCMV disease. pUL21.5 has been demonstrated to bind CCL5 with a high affinity and block the interaction of human CCL5 with specific cellular receptors (Wang et al., 2004). The interaction between pUL21.5 and CCL5 inhibits binding of the chemokine to its receptor, probably inhibiting migration, although this has not been formally proven. Due to the limited number of chemokines tested, it remains unclear whether this protein can bind chemokines other than CCL5. The exact role of this protein during infection is unknown. Inclusion of mRNAs in virions implies a role for at least a portion of pUL21.5 before the viral genome reaches the nucleus and begins to be transcribed, thus modulating the host response even before the transcriptional activation of the infecting viral genome (Wang et al., 2004).

\section{Chemokine-binding proteins encoded by $\gamma$-herpesviruses}

Members of the Gammaherpesvirinae subfamily infect lymphoblastoid cells in vitro and some also cause lytic infections in certain epithelial and fibroblastic cells. The host range is restricted to natural hosts and the viruses are specific for $\mathrm{B}$ and $\mathrm{T}$ lymphocytes, where the infection is frequently arrested, probably without the production of infectious progeny. Latent virus may be found in lymphoid tissue. These viruses are predominantly host-specific, so the virus vs host immune system interaction plays a crucial role in viral infection, particularly in latency establishment and reactivation from latency (Speck and Ganem, 2010). An ubiquitous $\gamma$-herpesvirus, EBV, prevalent in $90 \%$ to $95 \%$ of the human population, is clinically associated with various neurological diseases such as primary CNS lymphoma, multiple sclerosis, Alzheimer's disease, cerebellar ataxia, and encephalitis. EBV and KSHV are implicated in multiple malignancies. Similar to other herpesviruses, they establish life-long persistent infection, alternating between lytic replication and latency, while being subjected to the control of the host immune system. Only two known gammaherpesviral CKBPs designated as type III, M3 protein and R17 protein, were found in two animal $\gamma$-herpesviruses (Van Berkel et al., 1999; Heidarieh et al., 2015; Lubman et al., 2014). Murid herpesvirus 4 strain 68 (MuHV-4 or MHV68 ) is a natural pathogen of murid rodents used as an animal model for studying the pathogenesis of human lymphoproliferative disorders caused by EBV and KSHV. MHV-68 was originally isolated from wild rodent belonging to the Apodemus genus commonly infested with ticks (Blaškovič et al., 1980; Rajčáni and Kúdelová, 2005 and 2007). After the first discovery of MHV-68 in immature Ixodes ricinus ticks removed from wild green lizards, its occurrence was proved in free-living Dermacentor reticulatus, I. ricinus, and Haemaphysalis concinna ticks. Recently, experimental transmission of MHV-68 between I. ricinus ticks and mouse and vice versa proved that MHV68 could be vertically and horizontally transmitted from F0 to F1 tick generation, and thus, MHV-68 is suggested to be a tick-borne virus. (Hajnická et al., 2017; Kúdelová and Štibrániová, 2019). The recently characterized RHVP was found to be related to MHV-68 and KSHV; it was isolated from a lung homogenate of a pygmy rice rat (Oligoryzomys microtis) trapped in Peru (Loh et al., 2011).

The first herpesvirus protein able to bind chemokines was M3 protein encoded by MHV-68, a $44 \mathrm{kDa}$-secreted protein called vCKBP3. A recombinant MHV-68 virus lacking M3 gene expression, was found to be attenuated after intracerebral inoculation but had no effect on viral 
latency or the induction of chronic arteritis (van Berkel et al., 1999). These results suggest that virus attenuation is likely to be caused by the inability of the M3-deficient virus to block chemokine activity. Following the intranasal infection with MHV-68, virus lytically replicates in lungs and further spreads to the lymphoid tissue. This spread is not affected by the lack of the M3 gene expression, however, the establishment of latency in B-cells is impaired.. It was reported that pathogenesis of MHV-68, including the kinetics of $M 3$ gene expression, differed between neutral host wood mice and BALB/c or C57BL/6 mice, especially at 14 days post-infection. These models also differ during infection with viruses lacking M3. The lack of M3 gene expression was shown to affect the total viral load and virus-driven $B$ cell activation. The absence of M3 expression in the spleen results in missing germinal center formation and a reduction in the number of latently infected cells (Bridgeman et al., 2001; François et al., 2010; Hughes et al., 2011;). The results showed that the attenuation of MHV-68 correlates with differences in the leukocyte infiltration and suggested that MHV-68 infection induces the expression of several chemokines (Sarawar et al., 2002; vanBerkel et al., 2002).

The earliest studies on the biological properties of the 406 aa MHV-68 M3 showed that it is a unique soluble viral decoy receptor that binds a broad spectrum of chemokines with a high affinity, thus destabilizing chemokine networks in vitro and in vivo (Parry et al.,2000; van Berkel et al 2000; Jensen et al., 2003). It prevents chemokine-induced signal transduction in vitro and blocks the interaction of chemokines with their cellular receptors and the induction of intracellular signaling. In addition, M3 protein can block the interactions of chemokines with GAGs and also inhibit the formation of GAG-dependent chemokine gradients in vivo. High binding affinity of immunomodulatory M3 protein to chemokines of all four subfamilies was thoroughly studied. Characterization of M3 protein revealed affinities for CXC chemokines were lower compared with those for other subfamilies, suggesting a type of specificity. M3 protein blocks receptor binding by interacting with the $\mathrm{N}$-terminus of the chemokine and inhibits chemokine-mediated calcium mobilization and chemotaxis in vitro (Alcami, 2003b; Parry et al., 2000; van Berkel et al., 2000; Webb et al., 2003).

In most studies, the spectrum of chemokines that MHV-68 M3 protein is able to bind (either as a protein secreted into the media of virus-infected BHK-21 cells or as recombinant protein prepared in $E$. coli and/or insect cells) was identified by cross-linking assays with radiolabeled chemokines. Affinity to murine as well as human chemokines CCL5 (RANTES), CXCL8 (interleukin 8, IL-8), CCL3 (MIP-1a), CCL2 (MCP-1), and CCL11 (eotaxin-1) were tested (Parry et al., 2000; van Berkel et al., 2000).
In addition to the M3 protein of MHV68, the M3 of closely related murine herpesvirus strain MHV-72, isolated from the rodent Myodes glareolus (Blaškovič et al., 1980), was found to have a single mutation (D307G) near the chemokine-binding site. MHV-72 was found to differ in the genome sequence from MHV-68 with at least 30 codon-changing mutations (Halásová et al., 2011) and was reported to be attenuated in vivo and, thus, predicted to be more oncogenic (Nash et al., 2001). Belvončíková et al. (2008) first evaluated the binding of MHV-68 M3 protein secreted into the media of infected BHK-21 cells to human chemokines by ELISA tests. They compared MHV-68 M3 protein to its MHV-72 counterpart and demonstrated that both M3 proteins had the weakest affinity to CCL3 chemokine. MHV-72 M3 protein, with one natural mutation, bound to only $11 \%$ and $20 \%$, respectively, of the amount of CCL5 and CXCL8 bound by MHV-68 M3 protein.

MHV-68 M3 protein is an important point of interest, mainly after the pioneering work of Alexander et al.(2002), who used a recombinant baculovirus to produce enough full-length M3 protein in insect cells to determine its crystal structure to study its molecular and biological properties. They first reported the three-dimensional crystal structure of M3 protein both alone and in combination with CCL2/MCP-1. They demonstrated that MHV-68 M3 protein forms a tightly packed anti-parallel homodimer, in which the signal sequence (aa 1-24) is cleaved and five disulfide bonds are present. The model suggested how viral protein is able to bind chemokines despite having no a homology to the host's chemokine receptor. Due to the complex structure of M3 protein and a broad spectrum of chemokines that this protein is able to bind, however, the functions of its discrete domains are poorly understood.

In experiments, the strength of binding of MHV-68 M3 protein prepared in E. coli and Sf9 insect cells to several chemokines was quantified and compared, focusing on the inflammatory chemokine CCL5 (critical for T-lymphocyte, macrophage, eosinophil, and basophil activation, proliferation, and recruitment) and chemokine CXCL8 (which is highly involved in wound healing, triggers the infiltration of macrophages and neutrophils, and is associated with a highly metastatic phenotype of prostate cancer) (Inoue et al., 2000). Studies on the recombinant MHV-68 virus with M3 deletion prepared from Sf9 insect cells demonstrated that the deletion of the signal peptide allows stronger binding to CCL5 but not to CXCL8 (Šebová et al., 2017). Biochemical studies on recombinant M3 prepared in E. coli cells showed that the D307G substitution in MHV-72 M3 was responsible for a large decrease in its CCL3 binding relative to MHV-68 M3 (Pančík et al., 2013; Matúšková et al., 2015).

To better clarify the structural basis for the specific activity of MHV- $68 \mathrm{M} 3$, the impact of particular aa substi- 
tutions, E70A and T272G (located in its N- and C-terminal domain, respectively) on CCL5 and CXCL8 binding was studied. E70A mutation was found to enhance binding of M3 to CCL5 two-fold but had little effect on its binding to CXCL8. In contrast, the T272G mutation was important for the thermal stability of M3 and significantly decreased M3 binding to both CCL5 (by approximately $4 \times$ ) and CXCL8 (by approximately $5 \times$ ). Moreover, to gain better insight into M3 chemokine recognition, new in silico models of wtM3 complexes with CCL5 and CXCL8 were created and compared to the known X-ray crystal structures of wild type (wt) M3-CCL2 and wtM3-XCL1 complexes (Šebová et al., 2019).

Although data on the binding to individual chemokines are still rare, due to its broad-spectrum binding activity, M3 protein serves as a tool for understanding the chemokine network during homeostasis and in disease models (Martin et al., 2008; Lira et al., 2009). A variety of animal models have been developed to test the biological and pharmaceutical properties of M3 protein, but they are mainly related to its potential use in gene therapy. Induction of $M 3$ gene expression resulted in a $67 \%$ reduction in the intimal area of arteria, suggesting that M3 protein may be effective in attenuating intimal hyperplasia associated with arterial stenosis (Pyo et al., 2004). M3 protein expression overcame the cellular inflammatory responses in rat hepatocellular carcinoma lesions induced by a recombinant oncolytic vesicular stomatitis virus, prolonged the therapeutic effect of this virus, and improved animal survival (Wu et al., 2008). Recombinant M3 protein also inhibited angiogenesis and neovascularization (Andrés et al., 2009). The experimental autoimmune encephalomyelitis animal model showed that M3 protein treatment significantly reduced the number of immune cells infiltrating neurons, indicating that M3 protein treatment might represent a novel therapeutic approach to neuroinflammatory disease (Millward et al., 2010). Studies on double transgenic mice expressing both M3 protein and different chemokines in the pancreatic islets explored the role of chemokines and the effects of M3 protein on the development of diabetes mellitus type I. Moreover, mice expressing M3 protein in the pancreas have also been shown to be resistant to induced diabetes (Martin et al., 2008).

Studies on rhadinovirus RHVP confirmed that it can establish latent infection in B6 and 129 mice, with lethal infections observed in mice lacking interferon responses and/or B and T cells (Loh et al., 1996). The RHVP genome carries all of the conserved ORFs found in MHV-68 and $\mathrm{KSHV}$, as well as at least 18 unique ORFs that are not broadly conserved among other gammaherpesviruses. Sequence analysis of RHVP genome identified several proteins ( $\mathrm{R} 5, \mathrm{R} 6, \mathrm{R} 7, \mathrm{R} 17$, and $\mathrm{R} 18$ ) that are consistent with encoding secreted, extracellular proteins. They all contain leader peptides and lack both transmembrane regions and intracellular localization motifs, and are, thus, hypothesized to subvert host defense (Loh et al., 1996). Lubman et al. (2014) newly characterized R17 protein of RHVP as a potent chemokine inhibitor that sequesters $\mathrm{CC}$ and $\mathrm{C}$ chemokines with high (nanomolar) affinity, but not CX3C and the 6 CXC chemokines. The affinity and kinetics of chemokine binding by R17 and its mutant versions were measured using standard amine coupling of chemokines to R17 immobilized to a CM5 chip. Lubman and Fremont (2016) studied the crystal structures of RHVP R17 alone and in complex with CCL3 and determined that R17 consists of a pair of $\beta$-sandwich domains linked together by a bridging sheet that forms an acidic-binding cleft for chemokine CCL3 on the opposite face of a basic surface cluster that binds GAGs. R17 engages chemokines primarily through the same N-loop determinants used for host receptor recognition, while residues located in the chemokine 40s loop drive kinetically stable complex formation. The core fold adopted by R17 is unexpectedly similar to that of the M3 chemokine decoy receptor encoded by MHV-68, although, strikingly, neither the location of ligand engagement nor the stoichiometry of binding is conserved, suggesting that their functions evolved independently (Alexander et al., 2002). R17 protein enhances chemokine binding to cell surface GAGs through simultaneous interactions with both chemokines and GAGs. Interaction of R17 protein with GAGs takes place through two consensus BBXB motifs not involved in chemokine binding. These two sets of results indicate that R17 acts similar to M-T1 (myxomavirus CC-chemokine inhibitor) interacting with plasma membrane GAGs to inhibit chemokine activity in the proximity of infected cells (Seet et al., 2001). R17 protein blocks chemokine-induced chemotaxis and calcium influx in vitro, probably through the inhibition of the chemokine interaction with its receptor.

Comparison of the structures of two gammaherpesviral vCKBPs, M3 and R17 protein, coupled to chemokine shows an important difference between M3 and R17. While M3 protein binds CCL2 as a dimer, a monomer of R17 protein is present in the crystal bound to CCL3. Nevertheless, they both share a similar structural scaffold to interact with the chemokine, despite their very low amino acid identity (Lubman et al., 2014). The results of these studies show that RHVP R17 protein employs a similar structure as MHV-68 M3 protein to block chemokine-signaling networks. However, it is surprising that R17 has in parallel developed the capacity to sequester chemokines using determinants completely different from those employed by M3 protein of MHV-68 (Lubman and Fremont, 2016). 


\section{Perspective}

To date, only members of the Herpesviridae and Poxviridae families have been found to express vCKBPs, type I transmembrane or secreted proteins. Although these proteins display low or no sequence identity between themselves and host proteins, they all can bind and modulate chemokine activity of host immune response to viral infection. As reviewed herein, considerable research has been devoted to characterizing the biological properties of vCKBPs encoded by herpesviruses. It is currently unknown whether other large DNA viruses such as members of the Asfarviridae family or human poxvirus molluscum contagiosum virus also express these kinds of proteins. It is noteworthy that such proteins have not yet been discovered in human herpesviruses such as VZV, EBV, KSHV, HHV-6A and B, and HHV-7, although recent studies on VZV found a vCKBP in this virus (Heidarieh et al., 2015; González-Motos et al., 2016). Several studies have shown the presence of CKBP in more complex organisms than viruses, such as the Schistosoma mansoni parasite and ticks (Smith et al., 2005; Frauenschuh et al., 2007; Deruaz et al., 2008). Moreover, similar activity has been recently discovered in a human protein, TNF- stimulated gene/protein-6 (Dyer et al., 2014). The results of studies on CKBPs of viral (or non-viral) origins demonstrate some common features of the strategies developed by different pathogens to evade host response to infection. Although the mechanisms, through which vCKBPs are able to block the functions of chemokines and their receptors are still not fully understood (Proudfoot, 2002; Lucas and McFadden, 2004; Kufareva et al., 2015), further research in this field may uncover novel vCKBPs (not only of herpesviruses) to widen treatment strategies of human diseases related to chemokine network disorders.

Acknowledgments. This work was supported by the joint grant agency of the Slovak Ministry of Education and Slovak Academy of Sciences VEGA (\#2/087/17) and by the Slovak Research and Development Agency (\#APVV-0621-12 and APVV-15-0474).

\section{References}

Alcami A., Nature Rev. Immunol. 3, 36-50, 2003a. https://doi. org/10.1038/nri980

Alcami A., Trends Microbiol. 11, 191-192, 2003b. https://doi. org/10.1016/S0966-842X(03)00077-5

Alcami A, Koszinowski UH., Immunol. Today 21, 447-455, 2000. https://doi.org/10.1016/S0167-5699(00)01699-6

Alcami A and Lira S.A., Curr. Opp. Immunol. 22, 4824-87, 2010. https://doi.org/10.1016/j.coi.2010.06.004
Alcamí A, Symons JA, Collins PD, Williams TJ, Smith, GL, J. Immunol. 160, 624-633, 1998.

Alexander JM, Nelson CA, Van Berkel V, Lau EK, Studts JM, Brett TJ, Speck SH, Handel TM, Virgin HW, Fremont DH., Cell 111, 343-356, 2002. https://doi.org/10.1016/ S0092-8674(02)01007-3

Alexander-Brett JM and Fremont DH., J. Exp. Med.204,3157-3172, 2007. https://doi.org/10.1084/jem.20071677

Ali S, Palmer ACV, Banerjee B, Fritchley SJ, Kirby JA., J. Biol. Chem. 275, 11721-11727, 2000 https://doi.org/10.1074/ jbc.275.16.11721

Allen SJ, Crown SE, Handel TM., Annu. Rev. Immunol. 25, 787-820, 2007. https://doi.org/10.1146/annurev.immunol.24.021605.090529

Andrés G, Leali D D, Milota S, Coltrini D, Camozzi M, Corsini M, Belleri M, Hirsch E, Schwendener RA, Christofori G, Alcamí A, Presta M., J. Cell. Mol. Med.13, 2083-2108, 2009. https://doi.org/10.1111/j.1582-4934.2008.00415.x

Bachelerie F, Ben-Baruch A, Burkhardt AM, Combadiere C, Farber JM, Graham GJ et al., Pharmaco.1 Reviews 66,1-79, 2014a. https://doi.org/10.1124/pr.113.007724

Bachelerie F, Graham GJ, Locati M, Mantovani A, Murphy PM, Nibbs R. et al Nature Immunol. 15, 207-208, 2014b. https://doi.org/10.1038/ni.2812

Baggiolini M., Nature 392, 565-568, 1998. https://doi. org $/ 10.1038 / 33340$

Balan P, Davis-Poynter N, Bell S, Atkinson H, Browne H, Minson T., J. Gen. Virol. 75, 1245-1258, 1994. https://doi. org/10.1099/0022-1317-75-6-1245

Belperio JA, Keanem MP, Arenberg DA, Addison CL, Ehlert JE, Burdick MD, Strieter RM., J. Leuk. Biol. 68, 1-8, 2000a.

Belperio JA, Burdick MD, Keane MP, Xue YY, Lynch JP 3rd, Daugherty BL, Kunkel SL, Strieter RM., J. Immunol., 165, 461-472, 2000b. https://doi.org/10.4049/jimmunol.165.1.461

Belvončíková P, Král'ová A, Kúdelová M, Hajnická, Režuchová I, Vančová I., Acta Virol. 52, 91-97, 2008.

Blaškovič D, Stančeková M, Svobodová J, Mistríková J., Acta virol. 24, 468-473, 1980.

Bridgeman A, Stevenson PG, Simas JP, Efstathiou S., J. Exp. Med. 194,301-312,2001.https://doi.org/10.1084/jem.194.3.301

Bryant NA, Davis-Poynter N, Vanderplasschen A, Alcami A., EMBO J. 22, 833-846, 2003. https://doi.org/10.1093/ emboj/cdg092

Burg JS, Ingram JR, Venkatakrishnan AJ, Jude KM, Dukkipati A, Feinberg EN., et al., Science 347,1113-7, 2015. https:// doi.org/10.1126/science.aaa5026

Burns JM, Dairaghi DJ, Deitz, M, Tsang M, Schall TJ., J. Biol. Chem. 277, 2785-9, 2002. https://doi.org/10.1074/jbc. M109884200

Cabrera JR, Viejo-Borbolla A, Martinez-Martin N, Blanco S, Wandosell F., Alcami A., PLoSPathog. 11:e1004571, 2015. https://doi.org/10.1371/journal.ppat.1004571

Campbell DJ, Kim CH, Butcher EC., Immunol. Rev. 195, 58-71, 2003.https://doi.org/10.1034/j.1600-065X.2003.00067.x

Charo IF and Taubman MB., Circ. Res. 95, 858-866, 2004. https:// doi.org/10.1161/01.RES.0000146672.10582.17 
Chow MT and Luster AD., Cancer Immunol. Res. 2, 1125-1131, 2014. https://doi.org/10.1158/2326-6066.CIR-14-0160

Costes B, Ruiz-Arguello MB, Bryant NA, Alcami A, Vanderplasschen A., J. Gen. Virol. 86, 3209-3214, 2005. https://doi. org/10.1099/vir.0.81388-0

Dairaghi DJ, Greaves DR, Schall TJ., Semin. Virol. 8,377-385, 1998. https://doi.org/10.1006/smvy.1997.0146

Deruaz M, Frauenschuh A, Alessandri AL, Dias JM, Coelho FM, Russo RC, Ferreira BR, Graham GJ, Shaw JP, Wells TN, Teixeira MM., Power CA, Proudfoot AE., J. Exp. Med. 205, 2019-2031, 2008. https://doi.org/10.1084/ jem.20072689

Devlin JM, Viejo-Borbolla A, Browning GF, Noormohammadi AH, Gilkerson JR, Alcami A, Hartley CA., Vaccine 28, 1325-1332, 2010. https://doi.org/10.1016/j.vaccine.2009.11.013

Dyer DP, Thomson JM, Hermant A, Jowitt TA, Handel TM, Proudfoot AE. et al., J. Immunol. 192, 2177-2185, 2014. https://doi.org/10.4049/jimmunol.1300194

Engelhardt T and Keil GM., Virology 225, 126-135, 1996. https:// doi.org/10.1006/viro.1996.0580

Fernandez EJ and Lolis E., Ann. Rev. Pharmacol. Toxicol., 42, 469-499,2002. https://doi.org/10.1146/annurev.pharmtox.42.091901.115838

François S, Vidick S, Sarlet M, Michaux J, Koteja P et al., J. Gen. Virol. 91, 2553-2563, 2010. https://doi.org/10.1099/ vir.0.023481-0

Frauenschuh A, Power CA, Deruaz M, Ferreira BR, Silva JS, Teixeira MM, Dias JM, Martin T, Wells TN, Proudfoot AE., J. Biol. Chem. 282, 27250-27258, 2007. https://doi. org/10.1074/jbc.M704706200

Gomi Y, Sunamachi H, Mori Y, Nagaike K, Takahashi M, Yamanishi K., J. Virol. 76 , 11447-11459, 2002. https:// doi.org/10.1128/JVI.76.22.11447-11459.2002

González-Motoz V, Kropp KA, Viejo-Borbolla A., Cytokine Growth Factor Rev. 30, 71-80, 2016. https://doi. org/10.1016/j.cytogfr.2016.02.007

Graham KA, Lalani AS, Macen JL, Ness TL, Barry M, Liu LY et al., Virology 229, 12-24, 1997. https://doi.org/10.1006/ viro.1996.8423

Hajnická V, Kúdelová M, Štibrániová I, Slovák M, Bartíková P, Halásová Z, Pančík P, Belvončíková P, Vrbová M, Holíková V, Hails RS, Nuttall PA. Front. Cell. Inf. Microbiol. doi: 10.3389/fcimb.2017.00458, 2017. https:// doi.org/10.3389/fcimb.2017.00458

Halásová Z, Valovičová M, Mačáková K, Pančík P, Belvončíková P, Režuchová I, Kúdelová M., Acta Virol.55,317-325, 2011. https://doi.org/10.4149/av_2011_04_317

Heidarieh H, Hernaez B, Alcami A., Virus Res. 209, 67-75, 2015. https://doi.org/10.1016/j.virusres.2015.02.028

Hu Z and Usherwood EJ., Rev. Med. Virol. 24, 365-378, 2014. https://doi.org/10.1002/rmv.1791

Hughes DJ, Kipar A, Leeming GH, Bennett E, Howarth D, Cummerson JA et al., PLoSPathog. 7(3):e1001321, 2011. https:// doi.org/10.1371/journal.ppat.1001321

Inoue K, Slaton JW, Eve BY, Kim SJ, Perrotte P, Balbay MD, Yano S, Bar-Eli M, Radinsky R, Pettaway CA, Dinney CP., Clin. Cancer Res. 6, 2104-9, 2000.
Jensen KK, Chen S, Hipkin RW, Wiekowski MT, Schwarz MA, Chou Ch, Simas JP, Alcami A, Lira SA., J. Virol. 77, 624630,2003. https://doi.org/10.1128/JVI.77.1.624-630.2003

Johnson Z, Power CA, Weiss C, Rintelen F, Ji H, Rickle T, Camps M, Wells TNC, Schwarz MK, Proudfoot AEI et al., Biochem. Soc. Trans. 32, 366-377, 2004. https://doi. org/10.1042/bst0320366

Kimman TG, Pol JM, de Wind N, Oei-Lie N, Berns AJ, Gielkens AL., Vet. Microbiol. 33, 45-52, 1992. https://doi. org/10.1016/0378-1135(92)90034-Q

Kufareva I, Salanga CL, Handel TM., Immunol. Cell. Biol. 93, 372-383, 2015. https://doi.org/10.1038/icb.2015.15

Kúdelová M and Štibrániová I., Murine Gammaherpesvirus 68 (MHV-68), a Newly Discovered Tick Borne Virus. In: Ticks and Tick-Borne Pathogens (Abubakar M and Perera PK., eds.), London, UK, IntechOpen, Chapt 6 pp113-130, 2019. https://doi.org/10.5772/intechopen. 81025

Kuo NW, Gao YG, Schill MS, Isern N, Dupureur CM, Liwang PJ., J. Biol. Chem. 89, 6592-6603, 2012.

Lalani AS, Barrett J, McFadden G., Immunol. Today 21, 100-6, 2000. https://doi.org/10.1016/S0167-5699(99)01556-X

Lalani AS, Graham K, Mossman K, Rajarathnam K, Clark-Lewis I, Kelvin D, McFadden G., J. Virol. 71, 4356-4363, 1997. https://doi.org/10.1128/JVI.71.6.4356-4363.1997

Lalani AS, Ness TL, Singh R, Harrison, JK., Seet BT, Kelvin DJ et al., Virology 250, 173-184,1998. https://doi.org/10.1006/ viro.1998.9340

Lira SA, Viejo-Borbolla A, Shang L, Martin AP., Meth. Enzymol. 460, 193-207, 2009. https://doi.org/10.1016/S00766879(09)05209-4

Loh J, Zhao G, Nelson CA, Coder P, Droit L, Handley SA, Johnson LS, Vachharajani P, Guzman H, Tesh RB, Wang D, Fremont DH, Virgin H.W., J. Virol. 85, 2642-2656, 2011. https://doi.org/10.1128/JVI.01661-10

Lubman OY, Cella M, Wang X, Monte K, Lenschow DJ, Huang YH. et al., J. Virol. 88,538-546, 2014. https://doi.org/10.1128/ JVI.02729-13

Lubman OY and Fremont DH., Structure 24,57-69, 2016. https:// doi.org/10.1016/i.str.2015.10.018

Lucas A and McFadden G., J. Immunol. 173, 4765-4774, 2004. https://doi.org/10.4049/jimmunol.173.8.4765

Ludwig A and Weber C., Thrombosis and Haemostasis 97, 694-703, 2007. https://doi.org/10.1160/TH07-01-0035

Luo X, Wang X, Xia Z, Chung SK, Cheung CW., Reviews Neurosci. 27, 83-92, 2016. https://doi.org/10.1515/revneuro-2015-0016

Luster AD., N. Engl. J. Med. 338, 436-445, 1998. https://doi. org/10.1056/NEJM199802123380706

Mantovani R, Bonecchi M, Locati H., Nat. Rev. Immunol. 6, 907-918, 2006. https://doi.org/10.1038/nri1964

Martin AP, Canasto-Chibuque C, Shang L, Rollins BJ, Lira SA., J. Immunol.177,7296-7302,2006. https://doi.org/10.4049/ jimmunol.177.10.7296

Martin AP, Grisotto MG, Canasto-Chibuque C, Kunkel SL, Bromberg JS, Furtado GC et al., Diabetes 57, 387-394, 2008. https://doi.org/10.2337/db07-1309 
Martinez-Martin N, Viejo-Borbolla A, Martin R, Blanco S, Benovic JL, Thelen M, et al., Nature Commun. 6, 6163, 2015. https://doi.org/10.1038/ncomms7163

Matúšková R, Pančík P, Štibrániová I, Belvončíková P, Režuchová I, Kúdelová M., Acta Virol., 59, 360-8, 2015. https://doi. org/10.4149/av_2015_04_360

McFadden G and Murphy PM., Curr. Op. Microbiol.3,371-8, 2000. https://doi.org/10.1016/S1369-5274(00)00107-7

McGeoch DJ., J. Gen. Virol. 71, 2361-7, 1990. https://doi. org/10.1099/0022-1317-71-10-2361

Weber PC, Levine M, Glorioso JC., Science 236 (4801), 576-9, 1987. https://doi.org/10.1126/science.3033824

Millward JM, Holst PJ, Høgh-Petersen M, Thomsen AR, Christensen JP, Owens T., J. Neuroimmunol.224, 45-50, 2010. https://doi.org/10.1016/i.jneuroim.2010.05.005

Monneau Y, Arenzana-Seisdedos F, Lortat-Jacob H., J. Leuk. Biol. 99, 935-953, 2015. https://doi.org/10.1189/jlb.3MR0915440R

Moser B, Wolf M, Walz A, Loetscher P., Trends Immunol. 25, 75-84, 2004. https://doi.org/10.1016/i.it.2003.12.005

Mossman K, Nation P, Macen J, Garbutt M, Lucas A, McFadden G., Virology 215, 17-30, 1996. https://doi.org/10.1006/ viro.1996.0003

Murdoch C and Finn A., Chemokine receptors and their role in inflammation and infectious disease. Blood 95, 3032-3043, 2000. https://doi.org/10.1182/blood. V95.10.3032.010k17_3032_3043

Nash AA, Dutia BM, Stewart JP, Davison AJ., Phil Trans R Soc London, Ser B, 356, 569-579, 2001. https://doi. org/10.1098/rstb.2000.0779

Nelson CA, Epperson ML, Singh S, Elliott JI, Fremont DH., Viruses 7,4878-498,2015. https://doi.org/10.3390/v7092848

Pančík P, Bauerová-Hlinková V, Kúdelová M., Acta Virol. 57, 59-68, 2013. https://doi.org/10.4149/av 20130159

Parry BC, Simas JP, Smith VP, Stewart CA, Minson AC, Efstathiou S, Alcamí A., J. Exp. Med. 191, 573-8, 2000. https://doi. org/10.1084/jem.191.3.573

Proudfoot AE, Handel TM, Johnson Z, Lau EK, LiWang P, ClarkLewis I et al., Proc. Natl. Acad. Sci. U S A.100,1885-1890, 2003. https://doi.org/10.1073/pnas.0334864100

Proudfoot AEI., Nature Rev Immunol. 2, 106-115, 2002. https:// doi.org/10.1038/nri722

Pyo R, Jensen KK, Wiekowski MT, Manfra D, Alcami A, Taubman MB, Lira SA., Am. J. Pathol.164,2289-2297,2004. https:// doi.org/10.1016/S0002-9440(10)63785-6

Rajčáni J and Kúdelová M., Acta Microbiol. Immunol. Hung. 52, 41-71, 2005. https://doi.org/10.1556/AMicr.52.2005.1.2

Rajčáni J and Kúdelová M., Murid herpesvirus 4 (MHV-4): An animal model for human gammaherpesvirus research. In: Latency strategies of herpesviruses (Minarovits J, Gonczol E, Valyi-Nagy T, eds), Berlin, Heidelberg, New York, Springer, pp102-136, 2007. https://doi. org/10.1007/978-0-387-34127-9_5

Reading PC, Symons JA, Smith GL., J. Immunol. 170, 1435-1442, 2003. https://doi.org/10.4049/jimmunol.170.3.1435

Richman DD, Buckmaster A, Bell S, Hodgman C, Minson AC., J Virol. 57, 647-655, 1986. https://doi.org/10.1128/ JVI.57.2.647-655.1986
Roizman B and Pellet PE., The family herpesviridae: a brief introduction. In: Fields virology. (Knipe DM, Howley PM., eds.) Philadephia: Lippincott Williams\&Wilkins; pp2381-2398, 2001.

Rollins BJ., Blood. 90, 909-928, 1997. https://doi.org/10.1182/ blood.V90.3.909.909_909_928

Ross LJ, Binns MM, Pastorek J., J. Gen. Virol. 72, 949-954, 1991. https://doi.org/10.1099/0022-1317-72-4-949

Ruiz-Arguello MB, Smith VP, Campanella GS, Baleux F, Arenzana-Seisdedos F, Luster AD, et al., J. Virol. 82, 917-926, 2008. https://doi.org/10.1128/JVI.02111-07

Sallusto F and Baggiolini M., Nat. Immunol. 9, 949-952, 2008. https://doi.org/10.1038/ni.f.214

Sarawar SR, Lee BJ, Anderson M, Teng YC, Zuberi R, Von Gesjen S., Virology 293, 54-62, 2002. https://doi.org/10.1006/ viro.2001.1221

Seet BT and McFadden G., J. Leukocyte Biol. 72, 24-34, 2002.

Seet BT, Barrett J, Robichaud J, Shilton B, Singh R, McFadden, G. J. Biol. Chem. 276, 30504-30513, 2001. https://doi. org/10.1074/ibc.M011401200

Seet BT, Johnston JB, Brunetti CR, Barrett JW, Everett H, Cameron C, Sypula J, Nazarian SH, Lucas A, McFadden G., Ann. Rev. Immunol. 21, 377-423, 2003. https://doi. org/10.1146/annurev.immunol.21.120601.141049

Smith CA, Smith TD, Smolak PJ, Friend D, Hagen H, Gerhart M et al., Virology 236, 316-327, 1997. https://doi.org/10.1006/ viro.1997.8730

Smith P, Fallon RE, Mangan NE, Walsh CM, Saraiva M, Sayers JR et al., J. Exp. Med. 202, 1319-1325, 2005. https://doi. org/10.1084/jem.20050955

Speck SH and Ganem D., Cell Host Microbe 8, 100-115, 2010. https://doi.org/10.1016/j.chom.2010.06.014

Spriggs MK., Annu. Rev. Immunol. 14, 101-130, 1996. https://doi. org/10.1146/annurev.immunol.14.1.101

Šebová R, Bauerová-Hlinková V, Beck K, Nemčovicová I, Bauer J, Kúdelová M., Front. Cell. Inf. Microbiol. DOI: 10.3389/ fcimb.2019.00210, 2019. https://doi.org/10.3389/ fcimb.2019.00210

Thomsen DR, Marchioli CC, Yancey Jr. RJ, Post LE J. Virol. 61, 229-232, 1987. https://doi.org/10.1128/JVI.61.1.229232.1987

Upton C, Mossman K, McFadden G., Science 258, 1369-1372, 1992. https://doi.org/10.1126/science.1455233

Van Berkel V, Barrett J, Tiffany HL, Fremont DH, Murphy PM, McFadden G, Speck SH, Virgin HW., J Virol. 74, 6741-6747, 2000. https://doi.org/10.1128/JVI.74.15.6741-6747.2000

Van Berkel V, Preiter K, Virgin IV HW, Speck SH., J. Virol. 73, 4524-4529,1999. https://doi.org/10.1128/JVI.73.5.45244529.1999

Van de Walle GR, Kaufer BB, Chbab N, Osterrieder N., J. Biol. Chem. 284, 5968-5976, 2009. https://doi.org/10.1074/ jbc.M808127200

Van de Walle GR, Sakamoto K, Osterrieder N., J. Virol. 82, 1714-1722, 2008. https://doi.org/10.1128/JVI.02137-07

Viejo-Borbolla A, Martinez-Martin N, Nel HJ, Rueda P, Martin R, Blanco S et al., PLoSPathog.8:e1002497,2012. https:// doi.org/10.1371/journal.ppat.1002497 
Viejo-Borbolla A, Munoz A, Tabares E, Alcami A., J. Gen. Virol. 91, 23-31, 2010. https://doi.org/10.1099/vir.0.011940-0

von Einem J, Smith PM, Van de Walle GR, O'Callaghan DJ, Osterrieder N., Virology $362,151-162,2007$. https://doi. org/10.1016/j.virol.2006.12.008

Vossen MTM, Westerhout EM, Soderberg-Naucler C, Wiertz EJ., Immunogenetics 54, 527-542, 2002. https://doi. org/10.1007/s00251-002-0493-1

Wang D, Bresnahan W, Shenk T., Proc. Nat. Acad. Sci. USA 101, 16642-16647, 2004. https://doi.org/10.1073/ pnas.0407233101

Webb LMC, Clark-Lewis I, Alcami A., J. Virol.77, 8588-8592, 2003. https://doi.org/10.1128/JVI.77.15.8588-8592.2003
Weber M, Hauschild R, Schwarz J, Moussion C, deVries I, Legler DF et al., Science 339, 328-332, 2013. https://doi. org $/ 10.1126 /$ science. 1228456

Weber PC, Levine M, Glorioso JC., Science 236, 576-9, 1987. https://doi.org/10.1126/science.3033824

Wu L, Huang T, Meseck M, Altomonte J, Ebert O, Shinozaki K, García-Sastre A, Fallon J, Mandeli J, Woo SLC Hum. Gene. Ther. 19, 635-647, 2008. https://doi.org/10.1089/ hum.2007.163

Zlotnik A and Yoshie O., Immunity. 36, 705-716, 2012. https://doi. org/10.1016/j.immuni.2012.05.008

Zlotnik A, Yoshie O, Nomiyama H., Genome Biology 7,243-7, 2006 https://doi.org/10.1186/gb-2006-7-12-243 